\title{
Current views on fetal surgical treatment of myelomeningocele - the Management of Myelomeningocele Study (MOMS) trial and Polish clinical experience
}

\author{
Jacek Zamłyński, Ewa Horzelska, Mateusz Zamłyński, Katarzyna Olszak-Wąsik, \\ Leszek Nowak, Piotr Bodzek, Tomasz Horzelski, Rafał Bablok, Anita Olejek
}

Department of Gynecology, Obstetrics and Gynecologic Oncology in Bytom, Medical University of Silesia, Bytom, Poland

\begin{abstract}
Myelomeningocele (MMC) constitutes the most common congenital defect of the central nervous system, with no satisfactory alternative to the postnatal treatment. Prenatal repair of $\mathrm{MMC}$ is aimed at protecting from a Chiari type II malformation. The main goal of fetal MMC repair is to improve the development and quality of life in children with a Chiari type II malformation. The Management of Myelomeningocele Study (MOMS), which was published in 2011, confirmed the effectiveness of prenatal surgery. In this paper, we compared the MOMS results with our own clinical experience. Owing to high effectiveness and significant improvement in the safety of the maternal-fetal surgery, prenatal MMC repair has become a new standard of treatment.
\end{abstract}

Key words: myelomeningocele, prenatal surgery, spina bifida, Chiari malformation

Ginekologia Polska 2017; 88, 1: 31-35

\section{INTRODUCTION}

Fetal myelomeningocele ( $\mathrm{fMMC}$ ) is one of the most common neural tube defects (NTDs). The results of the current postnatal treatment are not satisfactory. Owing to significant advances in ultrasound diagnostic imaging and primary perinatal care, $\mathrm{FMMC}$ may be identified as early as 16-18 weeks of gestation. Early detection of different types of NTDs enables to arrange the delivery, followed by postnatal surgical treatment, in a tertiary referral center. However, only prenatal surgical treatment, known as the in utero MMC repair (IUMR), protects the fetus from developing a Chiari II malformation (CM II).

Fetal MMC, a serious congenital neural tube defect, is also the most common defect of the central nervous system [1]. The incidence of MMC in the USA has been estimated at 2/10 000 live births, whereas in Poland MMC affects approximately $6 / 10000$ live births $[2,3]$.

The risk factors for the development of fMMC include antispasmodic, antihistamine and sulfonamide drug use in pregnancy, maternal diabetes and obesity, as well as familial NTD. Insufficient folic acid supplementation and the presence of the $677 \mathrm{C}>\mathrm{T}$ polymorphism in the methylenetetrahydrofolate reductase gene are the key factors for developing NTD [4].

\section{POSTNATAL MMC REPAIR AND FOLLOW-UP IN CHILDREN WITH CM II}

Since the 1960s, postnatal MMC surgery technique of tensing the surrounding layers of fascia, muscles and skin with Limberg's modification has remained the primary treatment option, performed in the first 48 hours of life. Figure 1 shows newborns after delivery scheduled for postnatal MMC repair. In utero evolution of CM II entails serious neural defects, which are generally caused by hydrocephaly $(\mathrm{HC})$ and hindbrain herniation $(\mathrm{HH})$ [5]. As a consequence of spinal cord exposure to the amniotic fluid, motor function of the lower extremities is lost, and bladder and bowel dysfunction are observed [6]. Clinical 


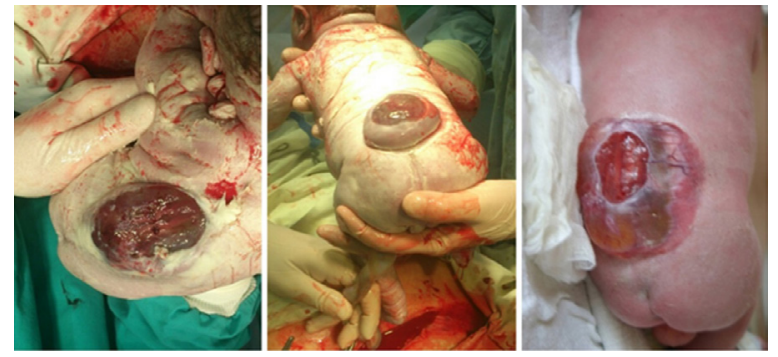

Figure 1. fMMC of three newborns delivered at 36-37 weeks for a scheduled operation after birth

implications depend on the level of spina bifida and spinal cord impairment. Defects lower down of the spinal cord are associated with better prognosis. A defect in cerebrospinal fluid circulation, which is caused by the displacement of the hindbrain structures into the spinal canal, results in $\mathrm{HC}$ in $80-90 \%$ of the children with $\mathrm{FMMC}$. About $80 \%$ of patients with $\mathrm{FMMC}$ require postnatal treatment such as endoscopic third ventriculostomy (ETV) or insertion of the ventriculoperitoneal shunt (VPS), which allows excess CSF to drain to the peritoneal cavity [7]. VPS placement is associated with numerous complications concerning its obstruction or infection [8]. Early Polish results of postnatal treatment show high rate $(85 \%)$ of progressive $\mathrm{HC}$ when temporary Rickham reservoir placement, followed by VPS insertion, was necessary [9].

The prognosis for children with MMC is grave. Despite intensive treatment, almost $14 \%$ of all children with MMC die during the first 5 years of life, and the mortality rate increases up to $35 \%$ when cerebellar dysfunction (secondary to CM II) develops [10]. About $70 \%$ of children reach the IQ level > 80, but only approximately half of them are self-reliant in adulthood [11].

\section{THE REASONS FOR PRENATAL FMMC SURGERY AND EARLY CLINICAL EXPERIENCES}

In 1990, Heffez et al., introduced the 'two-hit' theory, demonstrating a connection between neurological defects in children with MMC and the effect of two hits: neurulation in the early embryo life occurs, and then myelodysplasia is exaggerated in the mechanism of inflammation - the first hit (activated by the components of the amniotic fluid) - and mechanical destruction of spinal cord hitting the womb - the second hit [12].

Pathological and morphological studies on the spinal cord of fetuses (early and late pregnancy) and newborns with MMC reported progression of plaque defragmentation, spinal cord injury and nerve fiber destruction. These changes escalated with the duration of pregnancy [13].

The next experimental studies concerning IUMR in a sheep model disclosed that the loss of neurological function is then arrested. Especially, it became possible to main- tain the motor function of the lower extremities, sustain normal cortex width and vegetative functions [14].

Finally, an experimental study of IUMR in human fetus showed reversibility and even regression of $\mathrm{HC}$ and $\mathrm{HH}$, which are typical for CM II [15].

First IUMRs were reported in 1997-1998 at the Vanderbilt University Medical Center and at the Children's Hospital of Philadelphia (CHOP) $[16,17]$. Their early reports confirmed the theoretical and experimental assumption that in utero protection of the nerve fibers suppresses CM II evolution, resulting in $\mathrm{HH}$ reduction, stationary $\mathrm{HC}$ and maintaining motor function of the lower extremities $[18,19]$. In the follow-up study, the VPS implantation rate was lower in the IUMR group as compared to the group treated postnatally ( $90 \%$ vs. $46 \%$ ). The observed motor function of the lower extremities reflected motor functions typical for the injury of two spinal segments below the actual anatomical MMC level [19].

\section{THE MOMS RANDOMIZED STUDY RESULTS}

In 2011, the MOMS randomized study proved beyond any doubt the efficacy of prenatal surgery [20]. After enrollment and randomization of 183 out of the 200 recruited patients, the benefits of the prenatal surgery were confirmed and the study was completed. The rate of VPS placement in 1-year-old children who had undergone IUMR was significantly lower as compared to the postnatally treated patients ( $40 \%$ vs. $80 \%$; relative risk, $0.8 ; 97.7 \% \mathrm{Cl}, 0.36-0.64 ; \mathrm{p}<0.001)$. Motor function of the legs (at 30 months of follow-up) was also better in the prenatally treated children: $42 \%$ of the prenatally and $21 \%$ of the postnatally treated children (relative risk $2.01 ; 95 \% \mathrm{Cl}$, 1.16-3.48; $p=0.01$ ) could walk independently. Among children in the IUMR group, the rate of patients without $\mathrm{HH}$ was decreased as compared to the postnatally treated group (36\% vs. $4 \%$; relative risk $0.67 ; 95 \% \mathrm{Cl}, 0.56-0.81, \mathrm{p}<0.001)$. Vegetative dysfunctions, especially concerning bladder, are the most burdensome problems in MMC patients. Unfortunately, so far it has not been proven that surgical treatment in utero could favorably influence the functioning of the urinary system [21].

The MOMS study pointed out that iatrogenic complications, which arise from the invasiveness of the procedure, belong to the main IUMR limitations. IUMR increases the risk of iatrogenic preterm premature rupture of the membranes (iPPROM) (46\% vs. $4 \%$; relative risk $6.15 ; 95 \% \mathrm{Cl}, 2.75-13.78$; $\mathrm{p}<0.001$ ), oligohydramnios ( $21 \%$ vs. $4 \%$; relative risk 5.47 ; $95 \% \mathrm{Cl}, 16-18.4 ; \mathrm{p}<0.001)$ and inflammation-induced preterm labor (iPTL) (79\% vs. 15\%). As a result, higher incidence of children with low birth weight and respiratory distress syndrome is observed [20].

A five-year study of preschool children with MMC treated prenatally revealed that psychomotor development corresponded to their age in $83 \%$ of the cases. A 10 -year observational study showed that behavioral functions were normal 


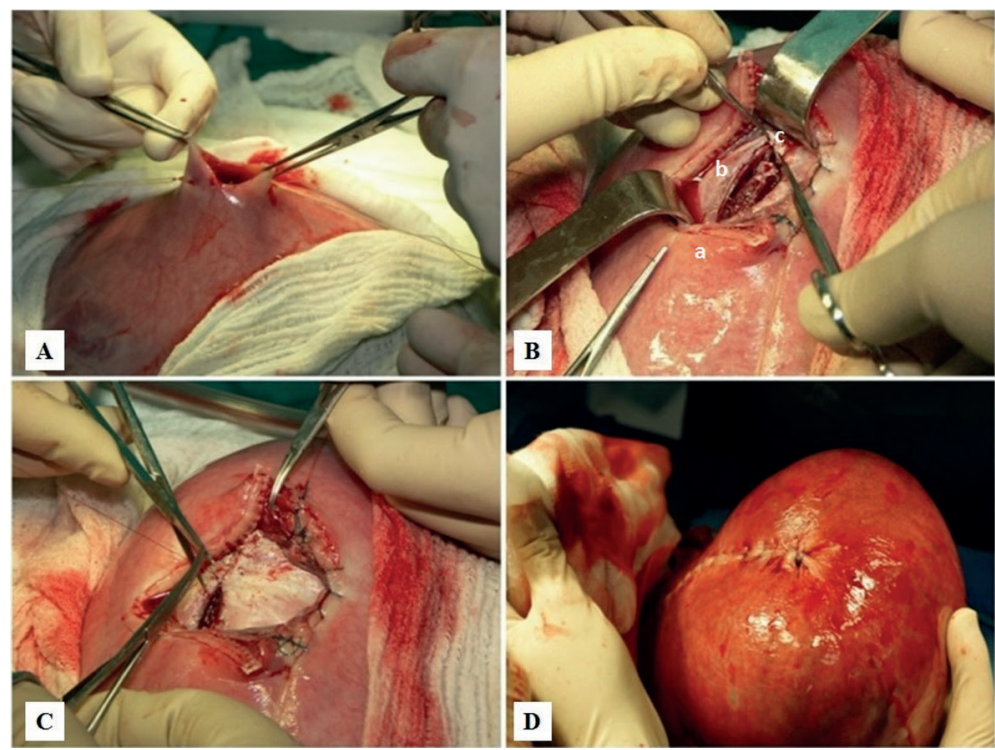

Figure 2. IUMR stages ( $A$ - hysterotomy; $B$ - stabilization of the fetus with exposed MMC a - uterus, b - fetal back, c - MMC sack; C — closed MMC; D — closed uterus)

in most patients and improvement of motor functions of legs was maintained in $90 \%$ of the affected children [23].

\section{FMMC REPAIR — POLISH CLINICAL EXPERIENCE}

In Poland, the first successful in utero $\mathrm{FMMC}$ repair was performed by Preis in 2004 [24]. Since 2005, 74 prenatal surgeries have been conducted at the Clinical Department of Gynecology, Obstetrics and Oncological Gynecology of the Silesian Medical University in Bytom, in cooperation with the pediatric surgeons from the Clinical Department of Pediatric Surgery in Katowice. In our first report on prenatal MMC closure in 10 patients, no increase in the lateral ventricular width was observed postoperatively [25]. Figure 2 demonstrates basic stages of IUMR. Since the surgery up to the delivery, the value remained within the qualification criterion of $<18 \mathrm{~mm}$. In the next report, concerning 31 IUMR cases, control fetal MRI revealed that 13 out of 19 fetuses demonstrated $\mathrm{HH}$ reduction and no progression was noticed in 6 cases [26]. In our non-randomized study, we compared a group of 46 fetuses treated in utero to $47 \mathrm{pa}-$ tients with MMC postnatal closure [28]. In this observation up to 53 months of life, decreased VPS implantation rate the first group ( $27.8 \%$ vs. $80 \%$; $\mathrm{Cl} 0.35,0.16-0.75 ; \mathrm{p}<0.008)$, lower $\mathrm{HH}(11 \%$ vs. $70 \%$; $\mathrm{Cl} 0.16,0.04-0.06, \mathrm{p}<0.01)$, and better motor function were noticed in the first group. As in the MOMS study, we demonstrated that prenatal surgery is associated with the risk of iPTL, iPPROM and uterine wound dehiscence. As a consequence of iPPROM and PPTL, advanced neonatal procedures are required. After IUMR surgery, the cumulative mortality among newborns $<7$ days of life reached $4.3 \%$ ( 2 newborns). In our last study of $71 \mathrm{fe-}$ tuses with $\mathrm{FMMC}$ treated in utero, reduced $\mathrm{HH}$ and station- ary HC were observed in $96.9 \%$ and $53.2 \%$ of the patients (36 cases), respectively. Only 15 newborns $(21.1 \%$ ) presented progressive $\mathrm{HC}$ ( $A D>95$ pct.). $29.5 \%$ of the pregnancies were delivered before 30 weeks of gestation and $18.3 \%$ ( 13 cases) reached 37 weeks of gestation. Cumulative mortality was $4.2 \%$ ( 2 newborns), and was comparable to the MOMS result of $3 \%$ ( 2 out of 78 cases) and to the recently published study of VUMC $-5 \%$ (3 out of 43 cases) [30].

\section{A NEW STANDARD — FETAL MMC CLOSURE. POST-MOMS ERA}

The main goal of prenatal MMC closure is to improve psychomotor development and the quality of life in patients with Chiari malformation. The latest studies, known as 'post-MOMS era' and published after 2011, showed high safety of the maternal-fetal surgery [13]. Bennet et al. compared the results of a cohort study of 43 pregnancies after IUMR with the results of the randomized MOMS study results, and demonstrated that improved technical skills in the IUMR procedure lowered the rate of iPPROM ( $22 \%$ vs. $46 \%$, $p=0.011)$ and chorioamniotic separation ( $0 \%$ vs. $26 \%$, $\mathrm{p}<0.001)$. Mean time of pregnancy after IUMR in the cohort study was extended up to $34.4 \pm 6.6$ vs. $34.1 \pm 3.1$ weeks of gestation. Also, the number of preterm births $<30$ weeks was reduced to $2(4 \%)$ vs. $10(13 \%)(p=0.08)$.

Satisfactory results of perinatal care in patients who underwent IUMR depend not only on the fetal-surgery team, but also on their understanding of the need to cooperate and achieve common goals [31]. Figure 3 presents an MMC site after prenatal surgery. The presented results have demonstrated high efficacy of IUMR. The studies from the last three decades have been finally accepted by the interna- 
Table 1. Criteria for fetal surgery

\begin{tabular}{|c|c|}
\hline Inclusion criteria & Exclusion criteria \\
\hline Gestational age: $20^{0}-25^{6}$ weeks & Fetal anomaly unrelated to myelomeningocele \\
\hline Maternal age $\geq 18$ years & $\begin{array}{l}\text { Pregestational diabetes } \\
\text { Severe kyphosis }\end{array}$ \\
\hline Width of lateral ventricle of the brain $A D<18 \mathrm{~mm}$ & $\begin{array}{l}\text { Isthmo-cervical insufficiency } \\
\text { Placenta previa } \\
\text { BMI } \geq 35\end{array}$ \\
\hline 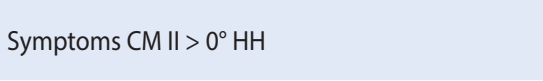 & $\begin{array}{l}\text { Gestational diabetes mellitus } \\
\text { Rh incompatibility }\end{array}$ \\
\hline $\begin{array}{l}\text { Myelomeningocele with the upper boundary } \\
\text { located between } \leq \mathrm{Th} 12-\geq \mathrm{S} 1\end{array}$ & $\begin{array}{l}\text { TORCH, HIV, HCV, HBS infection } \\
\text { Anatomical uterine anomaly } \\
\text { Contraindication for analgesia } \\
\text { No support from family or partner }\end{array}$ \\
\hline Bilateral leg movement & Hypertension, pre-eclampsia or eclampsia in current or previous pregnancy \\
\hline Singleton pregnancy & Epilepsy \\
\hline Normal karyotype & $\begin{array}{l}\text { Extremely low socioeconomic status } \\
\text { Lack of approval and understanding of the medical procedures to be offered } \\
\text { Lack of consent to prolonged hospitalization }\end{array}$ \\
\hline
\end{tabular}
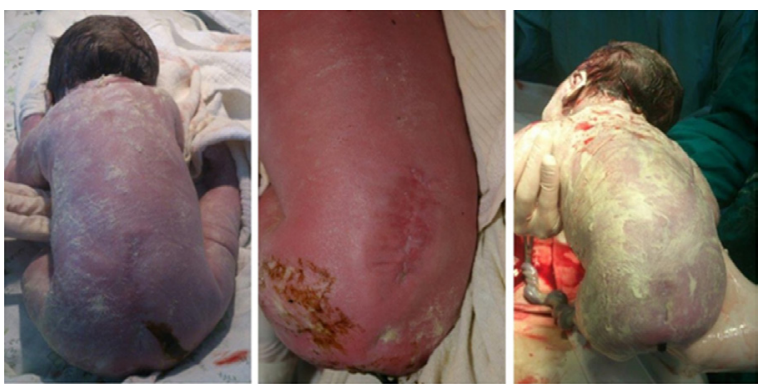

Figure 3. Result of prenatal MMC surgery of three newborns at 36-37 weeks of gestation, operated at the Department of Gynecology, Obstetrics and Gynecologic Oncology in Bytom, Medical University of Silesia (healed wound, no cerebrospinal fluid leak)

tional societies of obstetricians and gynecologists (ACOG, SOGC) for selected inclusion and exclusion criteria (Table 1) [32-34]. The Polish Gynecological Society published their recommendations about eligibility and the IUMR surgical procedure in 2006 [35].

\section{EDUCATION OF THE PARENTS AND THE APPROACH AFTER MMC DIAGNOSIS}

In cases when a NTD such as non-lethal fMMC is diagnosed, the parents should be informed about three possible treatment options:

- postnatal treatment performed within 24 hours of life,

- prenatal fMMC closure for patients who meet the eligibility criteria,

- pregnancy termination.

Medical consultation in cases when $\mathrm{FMMC}$ is diagnosed should not be directive. The decision of the prospective parents should be autonomous and based on the informa- tion presented during the consultation. Informed consent should be obtained.

If the parents decide to choose IUMR or if the consultation about $\mathrm{FMMC}$ is problematic, all necessary help and quick pre-qualification is provided also via e-mail: spinabifida@ o2.pl, phone number: 32 7861540, or personal consultation at the Department of Gynecology, Obstetrics and Gynecologic Oncology in Bytom, Medical University of Silesia, Stefana Batorego 15, 41-902 Bytom, Poland. Patients with diagnosed fMMC should not be referred for pregnancy termination without being fully informed about all possible treatment options.

\section{REFERENCES}

1. Timbolschi D, Schaefer E, Monga B, et al. Neural tube defects: the experience of the registry of congenital malformations of Alsace, France, 1995-2009. Fetal. Diagn. Ther. 2015; 37(1):6-17, doi: 10.1159/000362663, indexed in Pubmed: 25402326.

2. Boulet SL, Yang Q, Mai C, et al. National Birth Defects Prevention Network. Trends in the postfortification prevalence of spina bifida and anencephaly in the United States. Birth Defects Res. Part A Clin. Mol. Teratol. 2008; 82(7): 527-532, doi: 10.1002/bdra.20468, indexed in Pubmed: 18481813.

3. Latos-Bieleńska A, Materna-Kiryluk A, Badura-Stronka M, et al. Wrodzone wady rozwojowe w Polsce. Zespół Polskiego Rejestru Wrodzonych Wad Rozwojowych, Poznań 2010.

4. Seremak-Mrozikiewicz A. [The significance of folate metabolism in complications of pregnant women]. Ginekol. Pol. 2013; 84(5): 377-384, doi: 10.17772/gp/1593, indexed in Pubmed: 23819405.

5. Juranek J, Salman MS. Anomalous development of brain structure and function in spina bifida myelomeningocele. Dev Disabil Res Rev. 2010; 16(1): 23-30, doi: 10.1002/ddrr.88, indexed in Pubmed: 20419768.

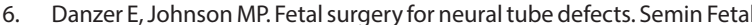
Neonatal Med. 2014; 19(1):2-8, doi: 10.1016/j.siny.2013.09.004, indexed in Pubmed: 24120287.

7. Lam S, Harris D, Rocque BG, et al. Pediatric endoscopic third ventriculostomy: a population-based study. J Neurosurg Pediatr. 2014; 14(5): $455-$ 464, doi: 10.3171/2014.8.PEDS13680, indexed in Pubmed: 25238625.

8. Maher CO, Goumnerova L, Madsen JR, et al. Outcome following multiple repeated spinal cord untethering operations. J. Neurosurg. 2007; 106(6 Suppl): 434-438, doi: 10.3171/ped.2007.106.6.434, indexed in Pubmed: 17566398 . 
9. Boczar M, Sawicka E, Piwowar W. Przepuklina oponowo-rdzeniowa — jak zmieniło się postępowanie podczas pierwszego etapu leczenia chirurgicznego wady. Ocena dwóch grup pacjentów leczonych w latach 1986-1992 oraz 1999-2005. Med Wieku Rozwoj. 2009; 13: 260-269.

10. Thompson DNP. Postnatal management and outcome for neural tube defects including spina bifida and encephalocoeles. Prenat. Diagn. 2009; 29(4): 412-419, doi: 10.1002/pd.2199, indexed in Pubmed: 19194999.

11. Adzick NS. Fetal myelomeningocele: natural history, pathophysiology, and in-utero intervention. Semin Fetal Neonatal Med. 2010; 15(1): 9-14, doi: 10.1016/j.siny.2009.05.002, indexed in Pubmed: 19540177.

12. Heffez DS, Aryanpur J, Hutchins GM, et al. The paralysis associated with myelomeningocele. Neurosurgery. 1990: 987, doi: 10.1097/00006123199006000-00011.

13. Meuli M, Moehrlen U. Fetal surgery for myelomeningocele is effective: a critical look at the whys. Pediatr. Surg. Int. 2014; 30(7): 689-697, doi: 10.1007/s00383-014-3524-8, indexed in Pubmed: 24908159.

14. Shen J, Zhou G, Chen H, et al. Morphology of nervous lesion in the spinal cord and bladder of fetal rats with myelomeningocele at different gestational age. J. Pediatr. Surg. 2013; 48(12): 2446-2452, doi: 10.1016/j. jpedsurg.2013.08.021, indexed in Pubmed: 24314185.

15. Paek BW, Farmer DL, Wilkinson CC, et al. Hindbrain herniation develops in surgically created myelomeningocele but is absent after repair in fetal lambs. Am. J. Obstet. Gynecol. 2000; 183(5): 1119-1123, doi: 10.1067/mob.2000.108867, indexed in Pubmed: 11084552.

16. Tulipan N, Bruner JP. Myelomeningocele repair in utero: a report of three cases. Pediatr Neurosurg. 1998; 28(4): 177-180, doi: 10.1159/000028645, indexed in Pubmed: 9732243.

17. Adzick N, Sutton $L_{,}$CrombleholmeT, et al. Successful fetal surgery for spina bifida. The Lancet. 1998; 352(9141): 1675-1676, doi: 10.1016/s01406736(98)00070-1.

18. Danzer E, Finkel RS, Rintoul NE, et al. Reversal of hindbrain herniation after maternal-fetal surgery for myelomeningocele subsequently impacts on brain stem function. Neuropediatrics. 2008; 39(6): 359-362, doi: 10.1055/s-0029-1202835, indexed in Pubmed: 19569004.

19. Danzer $\mathrm{E}$, Gerdes $\mathrm{M}$, Bebbington MW, et al. Lower extremity neuromotor function and short-term ambulatory potential following in utero myelomeningocele surgery. Fetal. Diagn. Ther. 2009; 25(1): 47-53, doi: 10.1159/000197359, indexed in Pubmed: 19174610.

20. Adzick NS, Thom EA, Spong CY, et al. MOMS Investigators. A randomized trial of prenatal versus postnatal repair of myelomeningocele. N. Engl. J. Med. 2011; 364(11): 993-1004, doi: 10.1056/NEJMoa1014379, indexed in Pubmed: 21306277.

21. Carr MC. Urological results after fetal myelomeningocele repair in pre-MOMS trial patients at the Children's Hospital of Philadelphia. Fetal. Diagn. Ther. 2015; 37(3): 211-218, doi: 10.1159/000362932, indexed in Pubmed: 25012042

22. Danzer E, Gerdes M, Bebbington MW, et al. Preschool neurodevelopmental outcome of children following fetal myelomeningocele closure. Am. J. Obstet. Gynecol. 2010; 202(5): 450.e1-450.e9, doi: 10.1016/j. ajog.2010.02.014, indexed in Pubmed: 20347433.

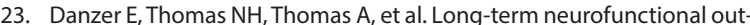
come, executive functioning, and behavioral adaptive skills following fetal myelomeningocele surgery. Am. J. Obstet. Gynecol. 2016; 214(2): 269.e1-269.e8, doi: 10.1016/j.ajog.2015.09.094, indexed in Pubmed: 26440692.

24. Sroka M, Świątkowska-Freund M, Gołębiewski A, et al. Chirurgia prenatalna: przyszłość czy ślepy zaułek: doświadczenia wstępne. Przegl Pediatr. 2007; 37: 7-9.

25. Zamłyński J, Olejek A, Bohosiewicz J, et al. [Perinatal results of intrauterine open fetal surgery of fetuses diagnosed with myelomeningocoele-the clinical report of ten cases]. Ginekol. Pol. 2007; 78(8): 647-651, indexed in Pubmed: 18050616.

26. Zamłyński J, Olejek A, Bohosiewicz J, et al. Kliniczne aspekty chirurgicznego zamknięcia przepukliny oponowo-rdzeniowej płodu z zespołem Chiari II. Perinatologia, Neonatologia i Ginekologia. 2010; 3: 41-47.

27. Bohosiewicz J, Koszutski T, Kowalik J, et al. Fetal repair of myelomeningocele in human fetuses. Experience related with 33 cases. Archives of Perinatal Medicine. 2011; 17: 81-84

28. Zamłyński J, Olejek A, Koszutski T, et al. Comparison of prenatal and postnatal treatments of spina bifida in Poland - a non-randomized, single-center study. J. Matern. Fetal. Neonatal. Med. 2014; 27(14): 1409-1417, doi: 10.3109/14767058.2013.858689, indexed in Pubmed: 24156622.

29. Olejek A, Zamłyński M, Olszak-Wạsik K, et al. Prenatal evolution of Chiari II malformation after intrauterine fetal MMC repair. Patients selection, maternal, fetal and neonatal results. Indian. J. Appl. Res. 2015; 5: 60-63.

30. Bennett KA, Carroll MA, Shannon CN, et al. Reducing perinatal complications and preterm delivery for patients undergoing in utero closure of fetal myelomeningocele: further modifications to the multidisciplinary surgical technique. J Neurosurg Pediatr. 2014; 14(1): 108-114, doi: 10.3171/2014.3.PEDS13266, indexed in Pubmed: 24784979.

31. Heuer GG, Adzick NS, Sutton LN. Fetal myelomeningocele closure: technical considerations. Fetal. Diagn. Ther. 2015; 37(3): 166-171, doi: 10.1159/000363182, indexed in Pubmed: 25171425.

32. American College of Obstetricians and Gynecologists. ACOG Committee opinion no. 550: maternal-fetal surgery for myelomeningocele. Obstet Gynecol. 2013; 121(1): 218-219, doi: http://10.1097/01. AOG.0000425666.02754.46, indexed in Pubmed: 23262964.

33. Wilson RD, Wilson RD, Audibert F, et al. SOGC Genetics Committee, Special Contributors, Society of Obstetricians and Gynaecologists of Canada. Prenatal screening, diagnosis, and pregnancy management of fetal neural tube defects. J Obstet Gynaecol Can. 2014; 36(10): 927-942, doi: 10.1016/s1701-2163(15)30444-8, indexed in Pubmed: 25375307.

34. Cohen AR, Couto J, Cummings JJ, et al. MMC Maternal-Fetal Management Task Force. Position statement on fetal myelomeningocele repair. Am. J. Obstet. Gynecol. 2014; 210(2): 107-111, doi: 10.1016/j.ajog.2013.09.016, indexed in Pubmed: 24055581.

35. Olejek A, Bohosiewicz J, Chilarski A, et al. Rozszczep kręgosłupa (spina bifida). Przepuklina oponowa-rdzeniowa (myelomeningocele). Rekomendacje Polskiego Towarzystwa Ginekologicznego. Ginekol Dypl. 2006; 8: 122-124 